Article

\title{
Perspectives of Private Forest Owners toward Investment in Forest Carbon Offset Projects: A Case of Geumsan-Gun, South Korea
}

\author{
Seunguk Shin 1 (1) and Youn Yeo-Chang $2, *$ (i) \\ 1 Department of Recreation, Sport and Tourism, University of Illinois at Urbana-Champaign, Champaign, \\ IL 61820, USA; sushin2@illinois.edu \\ 2 Department of Forest Sciences, Seoul National University, Seoul 08826, Korea \\ * Correspondence: youn@snu.ac.kr; Tel.: +82-2-880-4763
}

Received: 4 December 2018; Accepted: 30 December 2018; Published: 31 December 2018

check for updates

\begin{abstract}
Understanding and promoting South Korean private forest owners' investment in the Forest Carbon Offset (FCO) scheme is crucial for enhancing carbon sequestration using forests in South Korea. This study aims to identify the factors of private forest owners associated with the investment decision in FCO projects. A total of 132 forest owners in Geumsan-gun, Chungcheongnam-do responded to a mixed-method survey. A chi-square test on the respondent groups shows that a forest management contract has a positive correlation with the forest owners' willingness to invest in FCO projects. We also developed a logistic regression model for each forest owner group to estimate the effects of forest characteristics, experience of financial support, forest owner characteristics, and management characteristics on the forest owners' willingness to invest in FCO projects. The results indicate that beliefs in climate change, size of forest holdings, tree species, stand age, experience in cost-sharing for forestry operations with public agencies, and timber harvest experience were significantly associated with the likelihood of a forest owner's willingness to invest in FCO projects. Therefore, forest policies should take account of the factors influencing the likelihood of forest owners' investment in FCO projects. We also found that the forest management contract scheme can be used as a policy instrument for promoting private forest owners' action for climate change in South Korea.
\end{abstract}

Keywords: forest carbon offset; private forest owners; forest investment; forest management contract; logistic regression

\section{Introduction}

\subsection{Research Background}

South Korea's forested areas are about 6,369,000 ha and cover 63.8\% of the total domestic land surface [1]. The forests of South Korea are classified into three categories, namely, national forests owned by the central government; public forests owned by local governments; and private forests owned by individuals, clans, temples, churches, firms, and schools, which cover $25 \%, 8 \%$, and $67 \%$ of the total forest area, respectively. Although South Korea's timber demand is still growing, more than $80 \%$ of the total demand is met by imported timber. The quantity of timber imported is $24.9 \mathrm{million}^{3}$, while timber supplied from domestic forests was 4.8 million $\mathrm{m}^{3}$ in 2017 . The factors limiting timber supply from domestic forests include the age distribution of forests and high cost of timber production. In addition, there is a variety of government interventions regulating private forest management for public benefits such as erosion control and clean water supply.

Among forest ecosystem services, carbon sequestration of trees has been recognized as a strategy of South Korea's climate change mitigation. South Korea submitted its intended nationally determined 
contribution (INDC) to United Nations Framework Convention on Climate Change (UNFCCC) in 2015, proclaiming a national greenhouse gas emission reduction target of $37 \%$ lower than the business as usual (BAU) emission level in 2030. The South Korean government has formulated strategies for achieving the emission reduction target not only by reducing emissions, but also by enhancing carbon storage in forests. As forests are exclusively mentioned as carbon sinks in the Kyoto Protocol [2], the South Korean government introduced the Forest Carbon Offset (FCO) scheme in the Act on the Management and Improvement of Carbon Sink of 2013.

Forest owners can register FCO projects in their forests and acquire carbon offset credits for $\mathrm{CO}_{2}$ sequestered by the trees. The FCO credits are expected to be purchased by businesses for their social responsibility or to offset their greenhouse gas emissions in excess of the cap set by the government. There are six project methodologies in the FCO scheme, namely, Forest Development, Revegetation, Forest Management, Forest Biomass Energy, Wood Product Utilization, and Avoiding Conversion. Among these, the Forest Management methodology is considered the most appropriate for ordinary private forests because most of the private forests are in poor condition [3,4]. Forest Management FCO projects would be conducive to the general improvement of forest health and growth in South Korea.

Private forest owners should be in the frontline of the FCO scheme because they are potential major suppliers of the forest carbon offset credits. Among the total 204 FCO projects registered as of November 2018, 57 projects were registered by private forest owners [5]. Given that there are around 2.15 million private forest owners in the country, their participation in the FCO scheme is still in an early stage. Private forest owners' interests in the FCO scheme can be constrained by barriers to forest investment in general. As a domestic report [6] points out, private forest investment has been impeded by monotonous forest ages and species, a limited amount of labor and capitals, small tract sizes, and an increment of absentee forest owners. Although the enlargement of the private forests' investment in FCO project is crucial for vitalizing the FCO scheme, little is known about their perspectives toward investing in forest carbon. It is thus necessary to identify the underlying factors influencing the private forest owners' willingness to invest in FCO projects.

Another quest of our research on the private forest management for climate change mitigations in South Korea is about the potential of forest management contracts for private forests' role in the forest carbon business. The forest management contract scheme was institutionalized in 1997 by the Forestry and Mountain Villages Development Promotion Act, stating that a qualified professional forester can take over the management of private forests under a contract with the forest owner who lacks technical skills in managing the forest. The agent in contract with the forest owner is responsible for assisting the forest owner in making a forest management plan and implementing the forest operations specified in the plan. The forest management contract scheme has not yet succeeded in inviting many private forest owners [7-9]. Yet, there is still potential of the scheme to resolve challenges in facilitating private forest management such as aging and lack of interests in and skills of forestry of private forest owners [10-12]. We postulate that a forest management contract has the potential to lower barriers for forest owners to investment in FCO projects.

\subsection{Theory of Forest Investment}

McMahon's [13] theoretical discussion is useful to explain the behavior of a forest owner dealing with forest investment. Forested land is an asset of the owner from which profits can be generated by growing timber or non-timber forest products (NTFPs). To maximize the profits from management of the forest, the owner can invest in forest operations such as thinning, pruning, and roads construction. As an FCO project requires deliberate management actions with labor and capital inputs, it is deemed as an investment for private forest owners.

A forest owner seeks to maximize his or her utility by producing a combination of timber, NTFPs, and FCO credits. The forest owner's investment decisions are functions of the characteristics of investment, investor's characteristics, and the outcome of investment. The option is chosen when the aggregate expected utility from the investment option becomes the highest among all alternatives 
available. If a certain investment option is not expected to bring about enough utility for the investor, he or she would turn to alternatives such as investing in other items or merely consuming for other needs [13]. Figure 1 describes how investment and investor characteristics affect the total utility expected from an investment option.

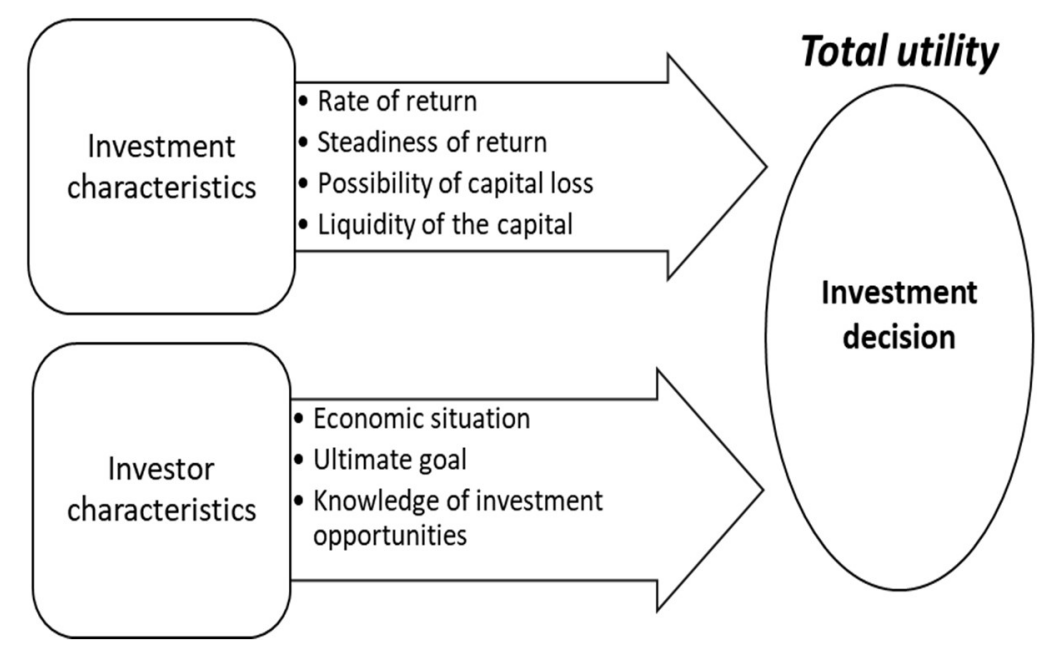

Figure 1. Total utility expected to be achieved from an investment option.

The investment option can be characterized by its earning capacity, rate of return, possibility of capital loss, and liquidity of capital assets. On the other hand, the investor is characterized by her or his investment competency, economic status, investment goals, and knowledge of investment opportunities. Once a forest owner decides to make an investment, she or he would compare all the alternative rates of returns of investment alternatives available, including forestry, to choose one that can maximize the investor's utility. Also, forest owners' subjective non-monetary satisfaction from their forests, for instance, sentimentalism, hobby, or recreational activities, are taken into account and have an influence on making an investment decision.

\subsection{Literature Review}

Existing literature on the determinants of forest investment has been focused on understanding the barriers and motivators of forest investment. There are a few studies conducted in South Korea [14,15] that identify factors related to private forest owners' forest investment based on McMahon's [13] forest investment theory. Although these studies are somewhat similar in their approaches and scopes, the factors influencing the forest owners' investment were reported differently. This mixed trend implies that the determinants of forest investment are consistent with the contextual changes such as introduction of new policy measures [16]. Therefore, forest owners' investment behaviors should be understood considering changing circumstances.

Studies conducted outside of South Korea can further broaden our perspectives because of their wide spectrum of investor and investment aspects toward various investment options, namely, harvest, reforestation, and forest conservation programs. Firstly, studies on investment in timber harvest indicate that the harvest decision is often mediated by revenue factors such as timber or stumpage prices, land size, forest owner's age, education and income levels, absentee ownership, timber revenue, debt ratio, and white-collar occupation [17-22]. Next, literature on reforestation investment reports that cost-sharing scheme, timber or pulp price, income level, technical assistance, replanting cost, agriculture dependence, owner's age, and absentee ownership were significant determinants of the reforestation decision [10,21,23-25]. Lastly, studies on private forest owners' participation in forest conservation programs, most of which emerged after the late 1980s, identify technical assistance, belief in the efficacy of the program, understanding of the program, income level, farming land, support for the program, desire for information, experience in forestry, land size, affiliation with forestry 
organization, owner's age, and absentee ownership as factors related to program participation [26-28]. Overall, a forest owner's investment behavior is associated with not only personal factors, but also exogenous components including investment options and investment conditions. Although the investment determinants have varying effects among different studies, the literature shows that a forest owner acts as a rational investor seeking to maximize satisfaction.

Recently, the forest owners have been deemed more as utility maximizers than merely profit maximizers because of the diversified objectives of their ownership [29]. There are several studies pointing out non-timber amenities acting as trade-offs against timber production [17,19] or as co-objectives with timber production [30]. Either group of the findings underpins the view that non-timber benefits, such as recreation and biodiversity, can be a forest owner's management objective.

Studies on the carbon benefits in South Korea have a relatively short history. Specifically, the efforts to understand private forest owners' behaviors and perception toward carbon are still in an incipient stage. Several domestic studies seek the feasibility of carbon-oriented forest management in private forests by calculating the optimum incentive level for maximizing forest carbon storage [3], estimating firms' willingness to pay for forest carbon credits [31], or estimating the opportunity cost of including carbon benefits in tree cutting ages [32]. Also, it has been reported that private forest owners are in need of financial, technical, informative, and administrative aids for investment in forest carbon projects $[33,34]$.

Research on the factors influencing private forest owners' participation in forest carbon projects, though not abundant, is often found outside of South Korea. Beginning with a pilot study [35] from Massachusetts, United States, a series of studies [36-42] on private or family forest landowners' willingness to participate in forest carbon projects have been conducted in various regions. Most of the studies highlight the barriers and incentives that affect forest owners' decision whether or not to implement forest carbon projects. The econometric approaches and methods used in these studies are comparable to those used in the traditional forest investment studies, which suggests that a forest carbon project can be construed as an investment opportunity that requires a reasonable decision-making process for utility maximization.

\subsection{Rationale}

There is little evidence on how South Korean private forest owners view investment in forest carbon projects such as an FCO project. Our research questions are formed in two phases. First, we want to answer the question, "What are the factors influencing private forest owners' willingness to invest in FCO projects?" The second question is, "Can a forest management contract play a positive role in private forest owners' investment decision in FCO projects?" The answers to these questions are expected to underpin climate change and forestry policy, providing prospects of forest management contracts and knowledge about the characteristics of the private forest owners who are more likely to invest in FCO projects.

\section{Materials and Methods}

\subsection{Site Selection and Survey Development}

To address the research questions, we designed a survey to gather information about the individual characteristics of forest owners. Accordingly, Geumsan-gun, Chuncheongnam-do was chosen as the research site because of its high proportion of private forests and active forestry operations.

The private forest owners in Geumsan-gun, estimated at 11,973 as of 2015, were divided into three groups. The first group is composed of 123 forest owners who had entered into forest management contracts (FMCs) with a forestry corporation (FC) based in Geumsan-gun. The FC functions as an agent, assisting the forest owners with forest management such as making a management plan, implementing management or harvest operations, and applying for subsidies. The second group consists of 134 forest 
owners in Geumsan-gun who are designated as forestry successors (FSs), a type of forest owners running forestry businesses, by Korea Forest Service (KFS). The third group is the rest of private forest owners neither in contract with the FC nor designated as an FS in Geumsan-gun. There are 11,716 forest owners of this type in Geumsan-gun.

Questionnaires were designed for the participants to fill out on their own. We implemented a pilot survey on nine forest owners in Geumsan-gun to make sure the questions and information on the sheet were easy to understand and appropriate for our research objectives. To deliver the questionnaires, we mailed them to the first and second forest owner groups, using their mailing addresses provided by the FC and the Korea FS Association, respectively. The tailored design method [43] was applied to the mail survey. When needed, additional phone calls were made at times to improve the response. Among the third group, we aimed to sample those more actively involved in forestry than the ordinary forest owners. Thus, we distributed the question sheets via the officials at the Forestry Policy Department, Geumsan-gun to the forest owners who had records of forestry practices at that moment. The questionnaires were distributed between 28 February and 24 March in 2017. Responses returned by 30 April 2017 were included for analysis.

\subsection{Variable Description}

The survey collected data on the respondents' investment characteristics and investor characteristics presumably related to the willingness to invest in FCO projects. The forest owners' yes-or-no responses to the question if they were willing to invest in FCO projects were intended to be a dependent variable (INVEST). To provide an example of an FCO project, we devised a model project with typical characteristics found in currently registered FCO projects at KFS by private forest owners. Table 1 describes these model project characteristics that are presented to survey participants. We intended to allow the respondents to apply the following conditions to their own situation to decide whether to invest in FCO projects. As of March 2017, project development costs and the registration fee were subsidized by the South Korean government. Forest carbon credits are assumed to be sold at $15,000 \mathrm{KRW} / \mathrm{tCO}_{2}$, which was the price offered by the government at that time [44]. Project opportunity costs that the forest owner should know included decreased timber revenue from delayed cutting and regeneration and inability to convert the land for other land use purposes. The question was phrased as, "Are you willing to invest in a Forest Carbon Offset project described above in your land?"

Table 1. Description of the model Forest Carbon Offset (FCO) project presented to the survey participants.

\begin{tabular}{|c|c|}
\hline Characteristic & Explanation \\
\hline Project description & $\begin{array}{l}\text { A forest management project that is used to issue forest carbon offset credits through } \\
\text { carbon sequestration from tree growth. }\end{array}$ \\
\hline Project costs & Project development costs and a registration fee are subsidized by the government. \\
\hline Expected revenue & $\begin{array}{l}\text { Credits will be sold at } 15,000 \mathrm{KRW} / \mathrm{tCO}_{2} \text {, which corresponds to } 80,000-100,000 \\
\mathrm{KRW} / \text { ha as expected revenue. }\end{array}$ \\
\hline Opportunity costs & $\begin{array}{l}\text { Timber revenue may decrease as a result of delayed harvest or change of tree species } \\
\text { for regeneration. }\end{array}$ \\
\hline Limitation & $\begin{array}{l}\text { Conversion of forest for other land use is prohibited during the project } \\
\text { implementation period of } 20 \text { to } 30 \text { years. }\end{array}$ \\
\hline
\end{tabular}

The definitions of explanatory variables are included in Table 2. The effect of each variable on the willingness was hypothesized based on previous studies. The variables postulated to influence private forest owners' interests in forest carbon offset investment include factors such as forest characteristics and experience in forestry support programs. Among the forest characteristics, forest size (FSIZE) was hypothesized to be positively related to investment because the literature suggests that the increasing forest size positively affects participation in forest carbon projects [36,38-40] and 
a stewardship program [45], as well as other forest investment options [18,19], mainly due to the profitability proportional to forest size. The fact that many forests in South Korea are becoming mature would affect forest owners' decision of whether to harvest or to invest in FCO projects. As older forests tend to be viewed as more apt for harvest as they reach or pass their cutting ages [15], average forest age class (FAGE) was thus expected to have a negative effect. Broadleaved trees (BROAD) as a dominant species was hypothesized to be positively associated with investment in the FCO project in South Korea. As timber prices of broadleaved species such as oak are lower than those of coniferous trees, broadleaved trees can sequester more carbon with less opportunity costs by delayed timber harvest, and thus be available for FCO projects.

Table 2. Definitions of explanatory variables.

\begin{tabular}{|c|c|c|}
\hline Variable & Definition & $\begin{array}{l}\text { Hypothesized Effect on } \\
\text { Dependent Variable }\end{array}$ \\
\hline \multicolumn{3}{|c|}{ Forest characteristics } \\
\hline FSIZE & \multirow{3}{*}{$\begin{array}{l}\text { Total amount of forest parcel(s) owned in hectare } \\
\text { Forest stand age class }(\mathrm{I}=1, \mathrm{II}=2, \mathrm{III}=3, \mathrm{IV}=4, \mathrm{~V}=5 \text {, and VI and older }=6 \text {; } \\
\text { class interval is } 10 \text { years) } \\
\text { Majority ( } 75 \% \text { and higher) of trees are broadleaved ( } 1 \text { if yes, } 0 \text { if otherwise) }\end{array}$} & Positive \\
\hline FAGE & & Negative \\
\hline BROAD & & Positive \\
\hline \multicolumn{3}{|c|}{ Experience in forestry support programs } \\
\hline COSTS & \multirow{2}{*}{$\begin{array}{l}\text { Experience in a cost-sharing program in past five years ( } 1 \text { if yes, } 0 \text { otherwise) } \\
\text { Experience in technical assistance or training in past five years ( } 1 \text { if yes, } \\
0 \text { otherwise) }\end{array}$} & Positive \\
\hline ASSIST & & Positive \\
\hline \multicolumn{3}{|c|}{ Forest owner characteristics } \\
\hline AGE & Forest owner age in years & Negative \\
\hline INCOME & $\begin{array}{l}\text { Annual income in million KRW }(0-10=1,10-20=2,20-30=3,30-40=4 \text {, and } \\
50 \text { or more }=5)\end{array}$ & Positive \\
\hline RESIDE & Residence in Geumsan-gun ( 1 if yes, 0 otherwise) & Negative \\
\hline EDU & $\begin{array}{l}\text { Highest education completed (no education }=1, \text { elementary }=2, \text { middle }=3, \\
\text { high }=4, \text { college }=5, \text { and graduate school }=6 \text { ) }\end{array}$ & Positive \\
\hline PURCHASE & Land acquired by purchase ( 1 if yes, 0 otherwise) & Positive \\
\hline ENVKNOW & $\begin{array}{l}\text { Common knowledge in environmental issues (one point for each of } \\
\text { five questions) }\end{array}$ & Positive \\
\hline ENVBELIEF & $\begin{array}{l}\text { Agreement with climate change statements (Likert scale } 1 \text { "Strongly disagree" } \\
\text { to } 5 \text { "Strongly agree") }\end{array}$ & Positive \\
\hline \multicolumn{3}{|c|}{ Management characteristics } \\
\hline ACTIVE & Active in forest production ( 1 if full-time or part-time forestry, 0 otherwise) & Negative \\
\hline HARVPAST & Timber harvested in the past ( 1 if yes, 0 otherwise) & Negative \\
\hline HARVPLAN & Plans to harvest in the future ( 1 if yes, 0 otherwise) & Negative \\
\hline PRODUCT & $\begin{array}{l}\text { Primary management purpose is making forest products ( } 1 \text { if yes, } \\
0 \text { otherwise) }\end{array}$ & Negative \\
\hline MGMTPLAN & Forest management plan established ( 1 if yes, 0 otherwise) & Positive \\
\hline
\end{tabular}

To investigate the effects of forestry support programs, we included forest owners' experience in forestry support programs as proxy variables. The cost-sharing program provides forest owners with differentiated amounts of subsidies depending on types of forestry practices. Because this measure would lower the investment barriers for forest owners [14,21,23,25], their experience of a cost-sharing program (COSTS) was hypothesized to have a positive effect on the investment in FCO projects. Also, experience of technical assistance program (ASSIST) was expected to be positively related to FCO investment, as the literature shows its positive role in promoting forest investment $[18,21,25,27]$.

The investor characteristics of a forest owner consist of socio-economic characteristics and management characteristics. A forest owner's age (AGE) was hypothesized to have a negative effect on FCO investment because older owners tend to regard their forests as a legacy rather than a viable investment option [14,39]. A variable indicating a forest owner's income level (INCOME) was hypothesized to have a positive effect on FCO investment because a wealthier forest owner has bigger financial capacity to afford forest investment $[13,20]$.

As the literature indicates that forest owners residing nearby their lands show greater interest in investment in forestry production than those living at further distances $[10,28]$, the related variable (RESIDE) was hypothesized to have a negative effect on FCO investment. The reason for this reversion 
is that forest owners living close to the land might prefer to invest in other options rather than carbon credits. The education level (EDU) of a forest owner, based on the highest education completed, was included and hypothesized to have a positive effect on FCO investment, as a recent study [38] found so. A forest owner who purchased the land by himself or herself was expected to be more likely to make forest investment to gain benefits than those who involuntarily took over or inherited land [22]. Therefore, the fact that a forest owner had purchased the land (PURCHASE) was hypothesized to positively affect his or her FCO investment. Both a forest owner's knowledge (ENVKNOW) of and beliefs (ENVBELIEF) in climate change and forest issues were hypothesized to have positive effects on FCO investment. In other words, those who are more knowledgeable of climate related issues and strongly believe that forests help mitigate climate change were deemed more likely to invest in FCO projects. Such variables were consistently reported to be positively associated with forest carbon program participation in previous studies [38-42].

The management characteristics included variables related to the forest owner's activities done on the forestland. The forest owner's engagement in forestry (ACTIVE), either full-time or part-time, was hypothesized to have a negative effect on FCO investment in that the forest owners would be reluctant to forgo their current timber income. The reason for this supposition is that in view of forest investment, the rate of monetary return of timber harvest overrides that of FCO credits [13]. A piece of literature [39] investigated forest owners' harvest experience, future harvest plan, and timber-oriented management, known to have positive effects on traditional forest investment, and found that they had negative effects on forest carbon program participation. This explains that there are possible conflicts between traditional forestry and forest carbon programs as forest owners' investment options. Thus, a forest owner's harvest experience (HARVPAST), future harvest plan (HARVPLAN), and management for producing forest products (PRODUCT) were hypothesized to be negatively associated with FCO investment. On the other hand, the requirement of a written forest management plan was perceived as a barrier for participation in forest carbon programs in earlier studies [36,39]. Accordingly, we inferred that forest owners who had previously formed a management plan (MGMTPLAN) would be more likely to invest in FCO projects than those yet to have management plans.

\subsection{Empirical Model}

A forest owner's utility derived from forest investment, similar to other investment problems, can be explained by a random utility model [46]. When it comes to FCO projects, a forest owner would try to maximize the utility by either investing in forest management practices required by the project or using the resource for other forestry or non-forestry investment options. The utility is modified by the investment opportunity characteristics and the investor characteristics, as discussed in the previous chapter. Therefore, the forest owner's willingness for FCO investment in this case is formulated as

$$
\mathrm{FCO}_{\mathrm{i}}=\mathrm{f}\left(\mathrm{O}_{\mathrm{i}}, \mathrm{P}_{\mathrm{i}}\right)+\varepsilon_{\mathrm{i}}
$$

where $\mathrm{FCO}_{i}$ is willingness to invest in an $\mathrm{FCO}$ project; $\mathrm{O}_{\mathrm{i}}$ is investment opportunity characteristics of an FCO project; $\mathrm{P}_{i}$ is personal characteristics of a forest owner as an investor; and $\varepsilon_{i}$ is a random error term.

Building on the conceptual framework described in (1), a logistic regression model was developed to estimate the probability of each group of the forest owners' investment in FCO projects. The dependent variable INVEST has a value of 1 if a forest owner indicated that they would invest in an FCO project, whereas it takes a value of 0 if a forest owner responded that they would not. When the probability that a forest owner will invest in an FCO project is $p$, the odds ratio is $p /(1-p)$. In the logistic regression, the log odds of the response take a form of linear regression:

$$
\text { Log odds }=\log \frac{p}{1-p}=\beta_{0}+\beta_{1} x_{1 i}+\beta_{2} x_{2 i}+\cdots+\beta_{m} x_{m i}
$$


where $p$ is the probability that a forest owner invests in an FCO project; $\beta_{0}$ is the intercept; $\beta_{m}$ is the vector of regression coefficients; and $x_{m i}$ is the vector of predictor variables.

In this study, we intended to estimate three logistic regression models using different compositions of the subjects to see the difference in factors concerning different types of forest owners. The first model (Model 1) included all the survey respondents, while the second model (Model 2) was divided by two sub-models one of which included forest owners with FMCs with the FC (Model 2-1) and the other included those without FMCs with the FC (Model 2-2). The statistics package used to estimate the probability was SPSS version 23.0.

\subsection{Impact of an FMC on Willingness to Invest in FCO}

We aimed to examine the difference of willingness to invest in FCO projects between forest owners with and without forest management contracts. Thus, we applied a chi-square test to the three sample groups of forest owners-namely, (1) forest owners with FMCs with the FC; (2) FS individuals; and (3) non-FS forest owners without FMCs with the FC (ordinary forest owners). In this study, we attempted to uncover whether there were any associations between the forest owner's willingness to invest in FCO projects and their characteristics. In particular, the effect of having an FMC on FCO investment decision was of a core interest.

We hypothesized that forest owners with FMCs with the FC would present greater willingness for FCO investment than the other groups of forest owners without FMCs. This was because forest owners receiving professional forestry technical service were considered to face lower barriers to engage in a new kind of investment $[18,25,27]$. However, it was also predicted that there could be forest owners from Group 2 and 3 who had forest management contracts. Those contracts would be considered not with the FC investigated in this study, but with other conventional entities such as the Forestry Cooperative and individual foresters. We also went the extra mile to compare the contracts by different type of FMC agency in terms of the forest owners' willingness to invest in FCO projects.

\section{Results}

\subsection{Survey Result}

The survey was conducted from 28 February to 30 April 2017. Samples collected from the three forest owner groups were categorized as Groups 1, 2, and 3 respectively. For Groups 1 and 2 combined, 257 questionnaires were distributed by mail, receiving 97 responses (response rate of $36.6 \%$ ). Then, 38 questionnaires from the direct delivery for Group 3 were added, making a total of 135 responses overall. In the mail survey of Groups 1 and 2, three responses were removed because they indicated that the forest owners had changed the land use to agriculture. On the other hand, all of the responses from Group 3 were either complete or subject to minor supplementary survey.

To address missing data, we used the Forest Geographic Information System (FGIS) provided by KFS for land information and a follow-up phone survey. FGIS provides each land's forest information such as land size, tree species and distribution, age class, and satellite image. We located each respondent's land address on the FGIS system and filled in the missing forest information. Also, we called those who did not answer personal and management information to gather the missing data. As a result, we could use 132 valid responses in total.

\subsection{Sample Description}

The socio-economic characteristics of the respondents are shown in Table 3. The mean age of all sample groups was 60.4 and the mean age of Group 1 was the highest among the three groups. In terms of education, $40.9 \%$ of the respondents were high school graduates and $31.1 \%$ were college graduates, consistent in all sample groups. Annual income, measured in KRW, was somewhat normally distributed with 20 to 30 million KRW in the center (20.5\%). However, Groups 2 and 3 presented relatively higher annual income than Group 1, which was inversely associated with their age 
distribution. KFS defines an absentee forest owner as an individual living in a different administrative area. More than half of the respondents (65.2\%) were residing in the jurisdiction of Geumsan-gun. The rest of them (34.8\%) were living outside of Geumsan-gun, being considered as absentee forest owners. This contrasts with the overall trend of the country, in which $44.1 \%$ of private forest owners reside in the same municipality as their forest holdings [1].

Table 3. Socio-economic characteristics of survey respondents.

\begin{tabular}{|c|c|c|c|c|c|c|c|c|c|c|}
\hline \multirow{2}{*}{\multicolumn{2}{|c|}{ Variable }} & \multicolumn{2}{|c|}{$\begin{array}{c}\text { All } \\
(n=132)\end{array}$} & \multicolumn{2}{|c|}{$\begin{array}{l}\text { Group } 1 \\
(n=62)\end{array}$} & \multicolumn{2}{|c|}{$\begin{array}{l}\text { Group } 2 \\
(n=32)\end{array}$} & \multicolumn{2}{|c|}{$\begin{array}{l}\text { Group } 3 \\
(n=38)\end{array}$} & \multirow[t]{2}{*}{$\chi^{2}$} \\
\hline & & Freq. $^{a}$ & $\%$ & Freq. $^{a}$ & $\%$ & Freq. $^{a}$ & $\%$ & Freq. $^{a}$ & $\%$ & \\
\hline \multirow{7}{*}{ Age } & Below 40 & 1 & 0.8 & 0 & 0 & 1 & 3.1 & 0 & 0.0 & \multirow{7}{*}{$\begin{array}{c}37.096 \\
(p=0.004)\end{array}$} \\
\hline & $41-50$ & 23 & 17.4 & 6 & 9.7 & 5 & 15.6 & 12 & 31.6 & \\
\hline & $51-60$ & 45 & 34.1 & 16 & 25.8 & 21 & 65.6 & 8 & 21.1 & \\
\hline & $61-70$ & 45 & 34.1 & 25 & 40.3 & 5 & 15.6 & 15 & 39.5 & \\
\hline & 71-80 & 16 & 12.1 & 13 & 21.0 & 0 & 0.0 & 3 & 7.9 & \\
\hline & 81 and older & 2 & 1.5 & 2 & 3.2 & 0 & 0.0 & 0 & 0.0 & \\
\hline & Mean & \multicolumn{2}{|c|}{60.4} & \multicolumn{2}{|c|}{64.3} & \multicolumn{2}{|c|}{55.1} & \multicolumn{2}{|c|}{58.6} & \\
\hline \multirow{5}{*}{ Education } & Elementary & 13 & 9.8 & 7 & 11.3 & 2 & 6.3 & 4 & 10.5 & \multirow{5}{*}{$\begin{array}{c}9.845 \\
(p=0.276)\end{array}$} \\
\hline & Middle school & 16 & 12.1 & 10 & 16.1 & 2 & 6.3 & 4 & 10.5 & \\
\hline & High school & 54 & 40.9 & 20 & 32.3 & 13 & 40.6 & 21 & 55.3 & \\
\hline & College & 41 & 31.1 & 20 & 32.3 & 12 & 37.5 & 9 & 23.7 & \\
\hline & Graduate & 8 & 6.1 & 5 & 8.1 & 3 & 9.4 & 0 & 0.0 & \\
\hline \multirow{6}{*}{$\begin{array}{l}\text { Annual } \\
\text { income } \\
\text { (million } \\
\text { KRW) }\end{array}$} & Less than 10 & 21 & 15.9 & 16 & 25.8 & 2 & 6.3 & 3 & 7.9 & \multirow{6}{*}{$\begin{array}{c}22.917 \\
(p=0.011)\end{array}$} \\
\hline & $10-20$ & 24 & 18.2 & 12 & 19.4 & 4 & 12.5 & 8 & 21.1 & \\
\hline & $20-30$ & 27 & 20.5 & 10 & 16.1 & 6 & 18.8 & 11 & 28.9 & \\
\hline & $30-40$ & 19 & 14.4 & 7 & 11.3 & 5 & 15.6 & 7 & 18.4 & \\
\hline & $40-50$ & 22 & 16.7 & 7 & 11.3 & 6 & 18.8 & 9 & 23.7 & \\
\hline & More than 50 & 19 & 14.4 & 10 & 16.1 & 9 & 28.1 & 0 & 0.0 & \\
\hline \multirow{2}{*}{ Residence } & Nearby & 86 & 65.2 & 37 & 59.7 & 23 & 71.9 & 26 & 68.4 & \multirow{2}{*}{$\begin{array}{c}1.634 \\
(p=0.442)\end{array}$} \\
\hline & Absentee & 46 & 34.8 & 25 & 40.3 & 9 & 28.1 & 12 & 31.6 & \\
\hline
\end{tabular}

When it comes to environmental knowledge, respondents were asked to answer five yes-or-no questions regarding climate change and forests. The number of questions answered correctly was scored in a range from 0 to 5 . As a result, the number of respondents with scores of 4 or 5 was $40.9 \%$ of the entire participants. Specifically, $46.8 \%$ and $50.0 \%$ of Groups 1 and 2, respectively, scored 4 or 5 , while $23.7 \%$ of Group 3 scored 4 or 5 .

To assess respondents' beliefs in climate change, we asked on what level respondents agree with each of three statements related to climate change and human activity on a Likert Scale (1-5 points for each statement). An aggregate point from the three statements equal to 12 and higher was considered to represent a strong belief in climate change. The survey results indicated that the percentages of respondents with strong beliefs in climate change were $75.8 \%, 90.6 \%$, and $84.2 \%$ in Groups 1,2 , and 3, respectively, showing no significant differences among groups.

The forest management characteristics of each group are summarized in Table 4. Group 2 showed a consistent tendency toward profit-oriented forest investment in that many of them had acquired lands by purchase, worked full-time or part-time in forestry, established management plans, prioritized forest products, participated in cost sharing, and received technical assistance. Also, the Group 2 respondents generally owned bigger forest land than the others. Regarding forest age distribution, 58.1\% of the Group 1 respondents had forests of age class I, while the majority of the Group 3 respondents had forests of age classes IV (42.1\%) and V (34.2\%). Many of the Group 2 respondents also had forests of age class IV and older, but the overall forest age distribution was more even than those of the other groups. 
Table 4. Forest management characteristics of survey respondents.

\begin{tabular}{|c|c|c|c|c|c|c|c|c|c|c|}
\hline \multirow{2}{*}{\multicolumn{2}{|c|}{ Management Characteristics }} & \multicolumn{2}{|c|}{$\begin{array}{c}\text { All } \\
(n=132)\end{array}$} & \multicolumn{2}{|c|}{$\begin{array}{l}\text { Group } 1 \\
(n=62)\end{array}$} & \multicolumn{2}{|c|}{$\begin{array}{l}\text { Group } 2 \\
(n=32)\end{array}$} & \multicolumn{2}{|c|}{$\begin{array}{c}\text { Group } 3 \\
(n=38)\end{array}$} & \multirow[t]{2}{*}{$x^{2 *}$} \\
\hline & & Freq. ${ }^{a}$ & $\%$ & Freq. ${ }^{a}$ & $\%$ & Freq. ${ }^{a}$ & $\%$ & Freq. $^{a}$ & $\%$ & \\
\hline \multicolumn{2}{|c|}{ Land purchased } & 43 & 32.6 & 11 & 17.7 & 20 & 62.5 & 12 & 31.6 & $19.275(p=0.000)$ \\
\hline \multicolumn{2}{|c|}{ Full-time or part-time forestry } & 54 & 40.9 & 20 & 32.3 & 26 & 81.3 & 8 & 21.1 & $29.660(p=0.000)$ \\
\hline \multicolumn{2}{|c|}{ Harvest in the past } & 49 & 37.1 & 23 & 37.1 & 8 & 25.0 & 18 & 47.4 & $3.724(p=0.155)$ \\
\hline \multicolumn{2}{|c|}{ Harvest in the future } & 33 & 25.0 & 16 & 25.8 & 9 & 28.1 & 8 & 21.1 & $0.504(p=0.777)$ \\
\hline \multicolumn{2}{|c|}{ Management plan established } & 39 & 29.5 & 9 & 14.5 & 14 & 43.8 & 16 & 42.1 & $12.709(p=0.002)$ \\
\hline \multicolumn{2}{|c|}{ Primary goal is forest products } & 37 & 28.0 & 7 & 11.3 & 20 & 62.5 & 10 & 26.3 & $27.515(p=0.000)$ \\
\hline \multicolumn{2}{|c|}{ Broadleaved forest } & 50 & 37.9 & 24 & 38.7 & 10 & 31.3 & 16 & 42.1 & $0.904(p=0.636)$ \\
\hline \multicolumn{2}{|c|}{ Experience in cost-sharing } & 36 & 27.3 & 21 & 33.9 & 12 & 37.5 & 3 & 7.9 & $10.242(p=0.006)$ \\
\hline \multicolumn{2}{|c|}{ Experience in tech assistance } & 51 & 38.6 & 7 & 11.3 & 17 & 53.1 & 27 & 71.1 & $39.231(p=0.000)$ \\
\hline \multirow{6}{*}{ Forest size (ha) } & $0-2.0$ & 34 & 25.8 & 15 & 24.2 & 4 & 12.5 & 8 & 21.1 & \multirow{6}{*}{$22.763(p=0.004)$} \\
\hline & $2.1-5.0$ & 43 & 32.6 & 21 & 33.9 & 7 & 21.9 & 22 & 57.9 & \\
\hline & $5.1-10.0$ & 21 & 15.9 & 9 & 14.5 & 5 & 15.6 & 7 & 18.4 & \\
\hline & $10.1-50.0$ & 29 & 22.0 & 15 & 24.2 & 13 & 40.6 & 1 & 2.6 & \\
\hline & 50.0 & 5 & 3.8 & 2 & 3.2 & 3 & 9.4 & 0 & 0.0 & \\
\hline & Mean & \multicolumn{2}{|c|}{9.77} & \multicolumn{2}{|c|}{9.97} & \multicolumn{2}{|c|}{16.83} & \multicolumn{2}{|c|}{2.5} & \\
\hline \multirow{6}{*}{$\begin{array}{c}\text { Forest stand age } \\
\text { class }\end{array}$} & $\mathrm{I}$ & 39 & 29.5 & 36 & 58.1 & 2 & 6.3 & 1 & 2.6 & \multirow{6}{*}{$55.699(p=0.000)$} \\
\hline & II & 11 & 8.3 & 3 & 4.8 & 6 & 18.8 & 2 & 5.3 & \\
\hline & III & 13 & 9.8 & 2 & 3.2 & 5 & 15.6 & 6 & 15.8 & \\
\hline & IV & 37 & 28.0 & 12 & 19.4 & 9 & 28.1 & 16 & 42.1 & \\
\hline & $\mathrm{V}$ & 28 & 21.2 & 7 & 11.3 & 8 & 25.0 & 13 & 34.2 & \\
\hline & VI and older & 4 & 3.0 & 2 & 3.2 & 2 & 6.3 & 2 & 6.3 & \\
\hline
\end{tabular}

a Number of responses. ${ }^{*}$ Chi-square statistics for dummy variables were acquired by using the frequencies of both

1 and 0 , although the frequencies of 0 were omitted for visibility.

\subsection{Logistic Regression Models}

Three logistic regression models were designed to identify determinants of the probability of forest owners' willingness to invest in FCO projects by estimating each model. Model 1 included all respondents $(n=132)$ along with all the explanatory variables listed in Table 2 . Then, subsamples with and without FMC were investigated. Model 2-1 included the subsample of forest owners with this type of FMC, who are Group 1 forest owners. Assumed to not have FMCs, both Group 2 and 3 were pooled and included in Model 2-2. A log likelihood ratio, pseudo- $R^{2}$, and Hoemer-Lemeshow test were used to examine the goodness of fit of each model. All models' goodness-of-fit statistics indicated that they had reliable fits for predicting the probability of the dependent variable. The results of model estimation are summarized in Table 5.

In Model 1 with all respondents, FSIZE, FAGE, BROAD, COSTS, ENVBELIEF, and HARVPAST were significantly related to willingness to invest in FCO projects. To interpret, forest owners whose forests are larger in area, younger in age, and broadleaved were more likely to invest in FCO projects. Also, those who had experienced a cost-sharing program expressed strong beliefs in climate change and human action, and those had not harvested timber in their forests were more likely to invest in FCO projects. Although not statistically significant, each of AGE, RESIDE, ACTIVE, PRODUCT, and MGMTPLAN had an impact on the dependent variable in the hypothesized direction.

Model 2-1 estimation indicated that the variables influencing Group 1 forest owners' willingness were somewhat different from those affecting the entire sample. BROAD, PURCHASE, ENVBELIEF, and MGMTPLAN had significant effects, which were all positive, as expected. In other words, among forest owners contracted with the FC, those who possessed broadleaved forests, purchased their lands, indicated strong beliefs in climate change and human action, or held forest management plans were more likely to invest in FCO projects. FSIZE, FAGE, ASSIST, AGE, EDU, and ACTIVE had coefficients in hypothesized ways, but showed no statistical significance.

Model 2-2 estimation reveals another set of variables significantly influencing the dependent variable. FSIZE, COSTS, and PRODUCT were the significant predictors of probability to invest in FCO projects among the forest owners in Group 2 and 3. Not statistically significant, but correctly hypothesized variables consisted of FAGE, BROAD, AGE, RESIDE, EDU, ENVKNOW, ENVBELIEF, ACTIVE, HARVPAST, and MGMTPLAN. 
Table 5. Regression coefficients and standard errors (in parentheses) of variables estimated in all three models. Dependent variable is whether a forest owner is willing to invest in an FCO project.

\begin{tabular}{ccccc}
\hline Variable & $\begin{array}{c}\text { Hypothesized } \\
\text { Effect }\end{array}$ & $\begin{array}{c}\text { Model 1 } \\
\text { All Respondents } \\
(\boldsymbol{n}=\mathbf{1 3 2})\end{array}$ & $\begin{array}{c}\text { Model 2-1 } \\
\text { Group 1 } \\
(\boldsymbol{n}=\mathbf{6 2})\end{array}$ & $\begin{array}{c}\text { Model 2-2 } \\
\text { Group 2 and 3 } \\
(\boldsymbol{n}=\mathbf{7 0})\end{array}$ \\
\hline FSIZE & Positive & $0.041^{* * *}(0.016)$ & $0.059(0.032)$ & $0.059^{* *}(0.025)$ \\
FAGE & Negative & $-0.322^{* *}(0.159)$ & $-0.106(0.256)$ & $-0.703(0.436)$ \\
BROAD & Positive & $0.843^{*}(0.446)$ & $1.931^{* *}(0.957)$ & $1.482(1.025)$ \\
COSTS & Positive & $1.259^{* *}(0.538)$ & $-0.150(0.908)$ & $3.702^{* * *}(1.264)$ \\
ASSIST & Positive & $-0.051(0.500)$ & $0.216(1.444)$ & $-0.258(0.868)$ \\
AGE & Negative & $-0.004(0.031)$ & $-0.014(0.064)$ & $-0.082(0.066)$ \\
INCOME & Positive & $-0.141(0.181)$ & $-0.209(0.337)$ & $-0.195(0.360)$ \\
RESIDE & Negative & $-0.727(0.501)$ & $0.961(1.059)$ & $-1.107(0.859)$ \\
EDU & Positive & $-0.124(0.297)$ & $0.026(0.606)$ & $0.308(0.560)$ \\
PURCHASE & Positive & $-0.048(0.504)$ & $2.457 *(1.361)$ & $-0.963(0.814)$ \\
ENVKNOW & Positive & $-0.051(0.173)$ & $-0.695(0.428)$ & $0.106(0.421)$ \\
ENVBELIEF & Positive & $0.370 * *(0.136)$ & $1.064 * *(0.346)$ & $0.281(0.311)$ \\
ACTIVE & Negative & $-0.282(0.487)$ & $-1.993(1.213)$ & $-0.087(1.042)$ \\
HARVPAST & Negative & $-0.868 *(0.516)$ & $0.172(0.903)$ & $-1.141(1.302)$ \\
HARVPLAN & Negative & $0.674(0.501)$ & $0.534(1.051)$ & $0.158(1.061)$ \\
PRODUCT & Negative & $-0.884(0.629)$ & $0.133(1.822)$ & $-3.002 * *(1.520)$ \\
MGMTPLAN & Positive & $0.532(0.531)$ & $5.618^{*}(2.886)$ & $0.315(0.878)$ \\
Constant & & $-1.572(2.815)$ & $-1.541(2.813)$ & $3.494(5.834)$ \\
Goodness-of-fit statistics & & & & \\
Log likelihood ratio $\left(\chi^{2}\right)$ & & $39.200(p=0.003)$ & $34.400(p=0.007)$ & $38.600(p=0.002)$ \\
Cox and Snell $\mathrm{R}^{2}$ & & 0.257 & 0.426 & 0.424 \\
Nigelkerke $\mathrm{R}^{2}$ & & 0.343 & 0.571 & 0.578 \\
Hosmer-Lemeshow $\left(\chi^{2}\right)$ & & $12.262(p=0.140)$ & $8.293(p=0.405)$ & $5.565(p=0.696)$ \\
\hline
\end{tabular}

${ }^{* * *}$ significant at $1 \%$ level, ${ }^{* *}$ significant at $5 \%$ level, ${ }^{*}$ significant at $10 \%$ level.

\subsection{Impact of Forest Management Contract on Willingness to Invest in an FCO Project}

In total, 61 out of 132 respondents answered that they were willing to invest in FCO projects. This percentage (46.2\%) of the willingness was very similar to $48 \%$, of a previous study [38] conducted in Norway. A chi-square test on the three sample groups (Table 6) showed that there were statistically significant $(p=0.074)$ differences among them at a $10 \%$ significance level, with the willingness of FCO investment being the highest in Group 1 (56.5\%), compared with Group $2(40.6 \%)$ and $3(34.2 \%)$, which were similar to each other.

Table 6. Difference of willingness to invest in FCO projects among sample groups.

\begin{tabular}{|c|c|c|c|c|c|c|c|c|c|}
\hline \multirow[t]{2}{*}{ Willingness } & \multicolumn{2}{|c|}{$\begin{array}{c}\text { All } \\
(n=132)\end{array}$} & \multicolumn{2}{|c|}{$\begin{array}{l}\text { Group } 1 \\
(n=62)\end{array}$} & \multicolumn{2}{|c|}{$\begin{array}{c}\text { Group } 2 \\
(n=32)\end{array}$} & \multicolumn{2}{|c|}{$\begin{array}{c}\text { Group } 3 \\
(n=38)\end{array}$} & \multirow[t]{2}{*}{$x^{2}$} \\
\hline & Freq. ${ }^{a}$ & $\%$ & Freq. ${ }^{a}$ & $\%$ & Freq. $^{a}$ & $\%$ & Freq. $^{a}$ & $\%$ & \\
\hline Yes & 61 & 46.2 & 35 & 56.5 & 13 & 40.6 & 13 & 34.2 & \\
\hline No & 71 & 53.8 & 27 & 43.5 & 19 & 59.4 & 25 & 65.8 & 5.219 \\
\hline Total & 132 & 100.0 & 62 & 100.0 & 32 & 100.0 & 38 & 100.0 & \\
\hline
\end{tabular}

a Number of responses.

Twenty of the respondents indicated that they had FMCs with other types of agencies than the FC, such as a forestry cooperative. To examine if those types of FMCs exert the same association as that shown by Group 1, we attempted to run chi-square test using this group. We referred to the 20 forest owners who had unknown FMCs as "Group A". A chi-square test (Table 7) including the combination of Group 1 and A did not present a statistical difference $(p=0.139)$ at a $10 \%$ significance level from respondents without FMC (which we called "Group B"). However, when we compared the forest owners engaging in FMCs with the FC (Group 1), the forest owners contracted with a non-FC agency, and forest owners without FMCs, there was a significant difference $(p=0.083)$ at a $10 \%$ significance level in another chi-square test. Group 1 showed the highest willingness rate (56.5\%), while Group A $(35.0 \%)$ and Group B (38.0\%) were similarly low in the willingness rate (Table 8$)$. 
Table 7. Difference of willingness to invest in FCO projects between the respondents with forest management contracts (FMCs) (Group 1+A) and those with no management contracts (Group B).

\begin{tabular}{|c|c|c|c|c|c|c|c|}
\hline \multirow[t]{2}{*}{ Willingness } & \multicolumn{2}{|c|}{$\begin{array}{c}\text { All } \\
(n=132)\end{array}$} & \multicolumn{2}{|c|}{$\begin{array}{l}\text { Group } 1 \text { and } A \\
\quad(n=82)\end{array}$} & \multicolumn{2}{|c|}{$\begin{array}{c}\text { Group B } \\
(n=50)\end{array}$} & \multirow[t]{2}{*}{$x^{2}$} \\
\hline & Freq. $^{a}$ & $\%$ & Freq. $^{a}$ & $\%$ & Freq. $^{a}$ & $\%$ & \\
\hline Yes & 61 & 46.2 & 42 & 51.2 & 19 & 38.0 & \multirow{3}{*}{$\begin{array}{c}2.184 \\
(p=0.139)\end{array}$} \\
\hline No & 71 & 53.8 & 40 & 48.8 & 31 & 62.0 & \\
\hline Total & 132 & 100.0 & 82 & 100.0 & 50 & 100.0 & \\
\hline
\end{tabular}

Table 8. Difference of willingness to invest in FCO projects among Group 1, A, and B.

\begin{tabular}{|c|c|c|c|c|c|c|c|c|c|}
\hline \multirow[t]{2}{*}{ Willingness } & \multicolumn{2}{|c|}{$\begin{array}{c}\text { All } \\
(n=132)\end{array}$} & \multicolumn{2}{|c|}{$\begin{array}{c}\text { Group } 1 \\
(n=62)\end{array}$} & \multicolumn{2}{|c|}{$\begin{array}{c}\text { Group A } \\
(n=20)\end{array}$} & \multicolumn{2}{|c|}{$\begin{array}{c}\text { Group B } \\
(n=50)\end{array}$} & \multirow[t]{2}{*}{$x^{2}$} \\
\hline & Freq. ${ }^{a}$ & $\%$ & Freq. $^{a}$ & $\%$ & Freq. $^{a}$ & $\%$ & Freq. ${ }^{a}$ & $\%$ & \\
\hline Yes & 61 & 46.2 & 35 & 56.5 & 7 & 35.0 & 19 & 38.0 & \\
\hline No & 71 & 53.8 & 27 & 43.5 & 13 & 65.0 & 31 & 62.0 & $\begin{array}{c}4.983 \\
(n-0083)\end{array}$ \\
\hline Total & 132 & 100.0 & 62 & 100.0 & 20 & 100.0 & 50 & 100.0 & $(p=0.083)$ \\
\hline
\end{tabular}

\section{Discussion}

\subsection{Model 1 Determinants of Forest Owners' Willingness to Invest in FCO Projects}

In Model 1, six variables were significant and showed hypothesized effects in a logistic regression. The positive coefficient of FSIZE implies that an FCO project, like other forestry investments, becomes more lucrative and efficient as the project land size gets larger $[18,40]$. It is also possible that forest owners with large forests could have intended to invest in FCO projects in parts of their lands to avoid the risk of investing the entire property. FAGE was shown to have a negative association with investment in FCO projects. Forests in higher age classes are closer to or may have passed their cutting ages, which is apt for timber harvest. Therefore, forest owners with older forests would have higher opportunity costs for delaying the harvest if they initiate FCO projects in their forests. This is consistent with a previous study [15] in South Korea, reporting that forest owners with older forests were more willing to invest in harvest. BROAD had a positive effect as well, indicating that forest owners might have supposed their broadleaved trees to not be profitable enough to produce timber, and thus available for FCO projects. In addition, it could be an effect of the South Korean government's promotion of broadleaved species based on their more effective climate change mitigation [47]. COSTS was positively associated with investment in FCO projects. This might be attributed to the perception of forest owners that FCO investment would be more affordable with a cost-sharing support. Respondents who had experience in a cost-sharing program would have been more familiar with its benefits and thus more willing to invest in FCO projects, which are subsidized by the government. Therefore, aligned with other forest investment behaviors reported in the literature [14,25], forest owners would feel lower barriers to FCO investment when financial support is provided. ENVBELIEF showed a positive association with investment in FCO projects. This met our expectation that forest owners who believe more in climate change and human responsibility would have stronger willingness to invest in climate change mitigation action using forests. This is also a replication of the outcome of a previous study [39] employing the same assessment tool for the variable. Another study explains this phenomenon that some forest owners view such actions as helping to mitigate an environmental issue they are concerned about [40]. HARVPAST had a negative coefficient, which means respondents who had harvested timber in past five years were less likely to invest in FCO project than those who had not. It is interpreted that those who had experienced earning revenue from timber production thought that the expected rate of return from FCO credits could not offset the opportunity cost of postponing 
timber harvest. Hence, the experienced forest owners may view an FCO project as a conflict with other traditional forest investment. This tendency was also found among a large forest owner group in Norway [38], calling for subsidies for delayed harvest induced by FCO projects [3].

Unexpectedly, ASSIST was not significantly associated with willingness to invest in FCO projects. This may be attributed to the fact that the technical assistance program for forest owners is strongly oriented to revenue-generating forest production [48]. Socio-economic variables such as AGE, EDU, and INCOME, and an investor characteristic ENVKNOW, did not have significant effects on FCO investment. In view of the forest investment theory, these characteristics might not be influential in a forest owner's ability as an investor when it comes to FCO projects. It is plausible that, for private forest owners, an FCO project does not require one to be a very competitive investor with sufficient resources and knowledge because of external support provided for them. Although forest owners' residence (RESIDE) was occasionally reported to be a significant variable for investment in traditional forestry $[10,28]$ or even a carbon program [40], our study sample did not replicate such results. The reason might be that many of the respondents in our study lived close to Geumsan-gun even though their municipalities were different. Therefore, there might be little difference between living in Geumsan-gun and living in nearby cities despite KFS's classification of forest owners by a municipality criterion. The non-significant effect of PURCHASE implies the same trend reported by a previous study [22], that PURCHASE was significant for investment in timber-oriented activities, but not in non-timber activities. In the South Korean context, family clans often buy forests to use them as their ancestors' graveyards. Thus, it is also possible that many of the lands purchased by the respondents were being used as graveyards, not for other forestry purposes. Variables closely related to production-oriented forestry, such as ACTIVE, HARVPLAN, PRODUCT, and MGMTPLAN, did not have significant impacts on willingness to invest in an FCO project. This makes us argue that an FCO project has intrinsically different aspects as an investment when compared with other forest investment alternatives covered in the literature.

From the results of Model 1, we can identify the critical FCO investment determinants that are different from the conventional forestry investment determinants discovered previously. In particular, variables related to promoting timber or non-timber forest products presented non-significant or reverse effects on FCO investment. This suggests that an FCO project is viewed by private forest owners as an inherently different investment opportunity from conventional forestry investment.

\subsection{Model 2 Determinants of Forest Owners' Willingness to Invest in FCO Projects}

The results of Model 2-1 and 2-2 show the comparative dispositions of respondents who had and did not have management contracts with the FC. FSIZE is the only significant variable in both models, being consistent with the result of Model 1. There are several variables found to be significant in either one of the models. Other than FSIZE, in Model 2-1, BROAD, PURCHASE, ENVBELIEF, and MGMTPLAN were found to be statistically significant and positively related to the willingness to invest in FCO projects. We could infer the same reasons as those we derived from Model 2-1 for BROAD and ENVBELIEF increasing the probability of FCO investment. BROAD was significant only in Model 2-1, perhaps because the respondents of Model 2-1 had technical assistance from the FMCs for FCO projects, whereas Model 2-2 respondents had few ways to overcome the difficulty. Therefore, the forest owners with broadleaved forests would consider investment in FCO projects once the difficulty in implementing FCO projects is alleviated by FMCs with the FC. PURCHASE was also significant only in Model 2-1. Therefore, among the Model 2-1 respondents, like other forestry investment decision makers, those who purchased land are more likely to invest in FCO projects than those who acquired land by other means (e.g., inherited). Unlike in Model 1 and Model 2-1, ENVBELIEF had a non-significant coefficient in Model 2-2, probably because these respondents were more likely to make an investment decision based on profits, not on environmental views. Having established a management plan (MGMTPLAN) had a positive correlation with the FCO investment probability only in Model 2-1. It is assumed that forest owners who held management plans would have been 
well informed by the FC and shown greater interest in forest investment. On the other hand, in addition to FSIZE, Model 2-2 suggests that COSTS and PRODUCT were significantly correlated with FCO investment decision. Similar to the landowners in previous studies $[14,21,23,25]$, experience in cost-sharing programs (COSTS) played a promotional role for FCO investment by lowering financial barriers of the Model 2-2 respondents. Also, the conventional forestry variable PRODUCT was found to negatively influence FCO investment probability, supporting the hypothesis that management for forest products would supersede generating carbon credits.

The results show differences of the two subsamples. When it comes to FCO investment, the Model 2-1 respondents can be characterized as a forest owner group that is less profit-oriented, with lower investment barriers, and with more consideration for the public good. In contrast, the Model 2-2 respondents present in part the characteristics of traditional private forest owners who are mostly inclined to reap benefits from their forest products. This implies that the use of FMCs with the FC can promote participation of private forest owners in FCO projects.

\subsection{Role of Forest Management Contract for Private Forest Owners}

The chi-square tests (Tables 6-8) suggest that a forest management contract can play a tangible role on private forest owners' investment in FCO projects. Participating in the FCO scheme requires technical and financial capacity, which private forest owners lack, and thus assistance from experts is called for [33]. A management contract with a forestry corporation can lower these barriers by sharing costs and providing technical assistance. Another interesting point we can infer from the results combined with our interaction with the survey respondents is that one of the important purposes of making a management contract is to harvest their old trees and replace them with a new tree species. With such a plan, the respondents may have considered an FCO project of regeneration with a new species of high carbon sequestration, which may be well-aligned with their intended forest management.

To broaden the perspective, it is expected that a forest management contract has the potential to enhance general private forest management in South Korea's situation. As seen in our sample, the private forest owners contracted with the FC represented those who are older and ignorant in forest management, and who passively inherited and do not invest in the land. Therefore, the forest management contract was being utilized by the private forest owners in such a need. In fact, documenting management plans and applying for cost-sharing and subsidies for practices were being executed by the FC on behalf of the forest owners. By this means, the FC can simultaneously manage multiple forest parcels with its concentrated capital and skills. Also, a forest management contract is typically established for a long term, such as 10 years, so that management can persist, which is critical for a long-term nature of forest investment.

However, it is worth noting that a forest management contract is not a panacea to improve the capabilities of private forest owners as investors. The agency problem is a management problem concerning the conflicts of interests between corporate insiders such as managers and outside investors like minority shareholders. The insiders controlling corporate assets can use the assets for themselves, compromising the interests of the other stakeholders [49]. The FC in this study is likely to act as an insider entity holding the decisive power on forest assets due to exclusive technical information and the forest owners' lack of interests in their forest investment. In interviews with the FC and its client forest owners, we noticed asymmetrical information and knowledge between them, which would be prone to the agency problem, where the FC can use the forests for their profits, regardless of the forest owners' interests.

\section{Conclusions}

The FCO scheme is not only considered an effective way to serve the goal of national greenhouse gas emission reduction, but also can provide various ecosystem services that improve the public's well-being. In South Korea, in which two-thirds of forests are owned by private hands, if the private 
forest owners are actively engaged in the FCO scheme, they can help accomplish the national emission reduction target. However, the prospects of the FCO scheme are fogged by adverse conditions of private forest management in South Korea. Lack of investment incentives and management capacity of the private forest owners makes it difficult to fathom their willingness to invest in FCO projects. We addressed this issue by investigating factors influencing private forest owners' investment decision and the role of a forest management contract regarding investment in FCO projects.

Reflecting on the forest investment theory [13], we inferred that private forest owners made decisions on FCO projects based on their characteristics as investors, as well as the attributes of the investment opportunity. The results show that the factors concerning investment in forest carbon and conventional forest production are different from each other, implying that an FCO project should be viewed as a non-traditional investment item for forest owners. Also, a forest management contract appeared to have a positive role in enhancing private forest owners' capacity as investors in FCO projects. Several measures can be derived from our study to attract private forest owners to the FCO scheme.

First, policymakers can refer to the characteristics of private forest owners who would be more interested in FCO project and pay selective attention to the high-willingness groups. Because our results show that large, younger, or broadleaved forest holders, those who had benefited from cost-sharing program or had not harvested timber before, were more likely to invest in FCO projects, identifying that such forest owners in the database would make a suitable group to which the promotion of the FCO scheme should be directed. The practice of FCO projects among such a group can become a model case for other forest owners who consider the same forest investment.

In addition, our study found that forest owners who believe in responsibility and roles of humans and forests for climate change were more willing to invest in FCO projects. This suggests that environmental awareness and beliefs should be grown among forest owners to boost their interests in FCO projects. Fostering social support for FCO projects can also motivate forest owners to invest in FCO projects. Both the current training programs for forest owners and social environmental education programs for the general public may as well incorporate a climate change education element.

Furthermore, a forest management contract can play a positive role for private forest owners' FCO investment by lowering barriers and building investment capacity. Policymakers would need to examine and improve relevant regulations to bolster the competitiveness of the forest management contract. This will also require additional efforts to keep professional foresters qualified for FCO project implementation through a contract. If properly operated along with existing policies, the forest management contract will ultimately contribute to improving private forest management in South Korea.

Lastly, compensation for the opportunity cost of FCO projects is needed. The forest owners who were producing forest products were likely to think of an FCO project as an unattractive investment option because of the predicted revenue loss. To make an FCO project an economically viable investment option, policy measures should recognize the value of assorted ecosystem services provided by forests. For instance, introducing a new credit system for non-timber forest amenities including biodiversity and water resource preservation can be a method to level the economic feasibility of non-timber forest investment such as an FCO project.

This study is in a position to build on the literature on private forest owners' participation in forest carbon projects. It can also diversify perspectives on private forest management in South Korea by shedding light on the investment aspect of FCO projects. In fact, our analysis provides an empirical case of factors involved in the forest owners' investment decision-making process suggested by the forest investment theory. However, limitations exist in that the results can hardly be generalized to the entire country, and in that we had predetermined the carbon price based on the government guideline, which does not reflect the real market supply and demand. Future study is needed to discover detailed preferences of private forest owners for forest carbon programs so that such a program can serve the interests of participants. 
Author Contributions: S.S. designed the research, conducted the survey and data analysis, interpreted the results, and wrote the first manuscript; Y.Y.-C. refined methods, interpreted the results, improved the discussion, and supervised the overall research.

Funding: This research was funded by Korea Forest Service, grant name Carbon Sink Graduate Program and grant number 500-20170054.

Acknowledgments: This paper is based on the master's thesis "Perspectives of private forest landowners toward investment in forest carbon offset projects: A case of Geumsan-gun, Korea" of Seoul National University.

Conflicts of Interest: The authors declare no conflict of interest.

\section{References}

1. Korea Forest Service. Statistical Yearbook of Forestry 2018; Korea Forest Service: Daejeon, Korea, 2018.

2. United Nations Framework Convention on Climate Change (UNFCCC). Kyoto Protocol to United Nations Framework Convention for Climate Change; UNFCCC: New York, NY, USA, 1998.

3. Han, K.; Youn, Y.-C. The feasibility of carbon incentives to private forest management in Korea. Clim. Chang. 2009, 94, 157-168. [CrossRef]

4. Chun, J.-N.; Youn, Y.-C.; Cha, J. Development of Korean protocol for forest carbon offset project in forest management sector. J. Environ. Policy Admin. 2012, 20, 57-87. [CrossRef]

5. Korea Forest Service. Forest Carbon Registry. Available online: http:/ / carbonregistry.forest.go.kr (accessed on 10 April 2017).

6. Jang, W.; Jang, C. The Measures Revitalizing Private Forest Cooperative Management; Korea Rural Economic Institute: Seoul, Korea, 1999; Research Paper R396.

7. Lee, S.-H. Study on the Revitalization of the Surrogate Management for Private Forests; Hankyong National University: Anseong, Korea, 2013.

8. Shin, S.-H. A Study on the Proxy Management System on the Private Forest; Chonnam National University: Gwangju, Korea, 2005.

9. Jang, I.-H. A Study on the Promotion Plan of Forestry Cooperatives in Korea; Kyungwon University: Seongnam, Korea, 2012.

10. Romm, J.; Tuazon, R.; Washburn, C. Relating forestry investment to the characteristics of nonindustrial private forestland owners in northern california. For. Sci. 1987, 33, 197-209.

11. Seo, B.S.; Lee, S.H.; Kang, H.M. A study on the management situation of private forest belonged to non-resident owners. Korean J. For. Econ. 1999, 7, 19-31.

12. Kim, H.-S.; Park, S.-I.; Lee, S.-H. An attitude of forest owners and importance-performance analysis for management-scale improvement on private forests. J. Agric. Life Sci. 2015, 49, 57-63. [CrossRef]

13. McMahon, R.O. Private Nonindustrial Ownership of Forest Land: An Economic Theory of Owner and Management Intensity; Yale University: New Haven, CT, USA, 1964.

14. Kim, N.G. Study on Landowner's Perception of Forest Investment and Incentive Policies for Private Forest Investment; Seoul National University: Seoul, Korea, 1992.

15. Seo, Y.W. Analysis of Determinants Affecting Investment of Private Forest Owners with Government Support Programs; Kangwon National University: Chuncheon, Korea, 2001.

16. Kim, E.-G.; Kim, D.-H.; Kim, H.-G. The analysis of the actual condition of planting investment of private forest owners. Korean J. For. Econ. 2005, 13, 47-55.

17. Binkley, C.S. Timber Supply from Private Nonindustrial Forests: A Microeconomic Analysis of Landowner Behavior; Yale University, School of Forestry and Environmental Studies: New Haven, CT, USA, 1981.

18. Boyd, R. Government support of nonindustrial production: The case of private forests. South. Econ. J. 1984, 51, 89-107. [CrossRef]

19. Conway, M.C.; Amacher, G.S.; Sullivan, J.; Wear, D. Decisions nonindustrial forest landowners make: An empirical examination. J. For. Econ. 2003, 9, 181-203. [CrossRef]

20. Dennis, D.F. An economic analysis of harvest behavior: Integrating forest and ownership characteristics. For. Sci. 1989, 35, 1088-1104.

21. Hyberg, B.T.; Holthausen, D.M. The behavior of nonindustrial private forest landowners. Can. J. For. Res. 1989, 19, 1014-1023. [CrossRef] 
22. Joshi, S.; Arano, K.G. Determinants of private forest management decisions: A study on west virginia nipf landowners. For. Policy Econ. 2009, 11, 118-125. [CrossRef]

23. Brooks, D.J. Public policy and long-term timber supply in the south. For. Sci. 1985, 31, 342-357.

24. De Steiguer, J.E. Notes: Impact of cost-share programs on private reforestation investment. For. Sci. 1984, 30, 697-704.

25. Royer, J.P. Determinants of reforestation behavior among southern landowners. For. Sci. 1987, 33, 654-667.

26. Bell, C.D.; Roberts, R.K.; English, B.C.; Park, W.M. A logit analysis of participation in tennessee's forest stewardship program. J. Agric. Appl. Econ. 1994, 26, 463-472. [CrossRef]

27. Esseks, J.D.; Kraft, S.E. Why eligible landowners did not participate in the first four sign-ups of the conservation reserve program. J. Soil Water Conserv. 1988, 43, 251-256.

28. Nagubadi, V.; McNamara, K.T.; Hoover, W.L.; Mills, W.L. Program participation behavior of nonindustrial forest landowners: A probit analysis. J. Agric. Appl. Econ. 1996, 28, 323-336. [CrossRef]

29. Amacher, G.S.; Conway, M.C.; Sullivan, J. Nonindustrial Forest Landowner Research: A Synthesis and New Directions; General Technical Report (GTR)-SRS-075; US Department of Agriculture, Forest Service, Southern Research Station: Asheville, NC, USA, 2004; Chapter 22, pp. 241-252.

30. Pattanayak, S.K.; Murray, B.C.; Abt, R.C. How joint is joint forest production? An econometric analysis of timber supply conditional on endogenous amenity values. For. Sci. 2002, 48, 479-491.

31. Roh, T.; Koo, J.-C.; Cho, D.-S.; Youn, Y.-C. Contingent feasibility for forest carbon credit: Evidence from south korean firms. J. Environ. Manag. 2014, 144, 297-303. [CrossRef]

32. Kim, M.E. Opportunity Costs of Carbon Offsets Project to Private Forest Owners in Korea; Seoul National University: Seoul, Korea, 2013.

33. Park, M.S.; Koo, J.-C.; Jang, E.-K.; Choi, J.; Han, K. Incentives for vitalizing korean forest carbon offset projects. J. Environ. Policy Admin. 2014, 22, 1-26. [CrossRef]

34. Maraseni, T.N.; Dargusch, P. Expanding woodland regeneration on marginal southern queensland pastures using market-based instruments: A landowners' perspective. Australas. J. Environ. Manag. 2008, 15, 104-112. [CrossRef]

35. Fletcher, L.S.; Kittredge, D.; Stevens, T. Forest landowners' willingness to sell carbon credits: A pilot study. Northern J. Appl. For. 2009, 26, 35-37.

36. Dickinson, B.J. Massachusetts Landowner Participation in Forest Management Programs for Carbon Sequestration: An Ordered Logit Analysis of Ratings Data; University of Massachusetts: Amherst, MA, USA, 2010.

37. Dickinson, B.J.; Stevens, T.H.; Lindsay, M.M.; Kittredge, D.B. Estimated participation in US carbon sequestration programs: A study of nipf landowners in massachusetts. J. For. Econ. 2012, 18, 36-46.

38. Håbesland, D.E.; Kilgore, M.A.; Becker, D.R.; Snyder, S.A.; Solberg, B.; Sjølie, H.K.; Lindstad, B.H. Norwegian family forest owners' willingness to participate in carbon offset programs. For. Policy Econ. 2016, 70, 30-38. [CrossRef]

39. Markowski-Lindsay, M.; Stevens, T.; Kittredge, D.B.; Butler, B.J.; Catanzaro, P.; Dickinson, B.J. Barriers to massachusetts forest landowner participation in carbon markets. Ecol. Econ. 2011, 71, 180-190. [CrossRef]

40. Miller, K.A.; Snyder, S.A.; Kilgore, M.A. An assessment of forest landowner interest in selling forest carbon credits in the lake states, USA. For. Policy Econ. 2012, 25, 113-122. [CrossRef]

41. Tian, N.; Poudyal, N.C.; Hodges, D.G.; Young, T.M.; Hoyt, K.P. Understanding the factors influencing nonindustrial private forest landowner interest in supplying ecosystem services in cumberland plateau, tennessee. Forests 2015, 6, 3985-4000. [CrossRef]

42. Thompson, D.W.; Hansen, E.N. Factors affecting the attitudes of nonindustrial private forest landowners regarding carbon sequestration and trading. J. For. 2012, 110, 129-137. [CrossRef]

43. Dillmann, D.A.; Smyth, J.D.; Christian, L.M. Internet, Mail, and Mixed-Mode Surveys: The Tailored Design Method; Wiley: Hoboken, NJ, USA, 2009.

44. Kim, Y.-H. Analysis of the average abatement cost of forest carbon offset projects for the government purchase of forest carbon credits. J. Clim. Chang. Res. 2016, 7, 391-396. [CrossRef]

45. Kilgore, M.A.; Snyder, S.; Taff, S.; Schertz, J. Family forest stewardship: Do owners need a financial incentive? J. For. 2008, 106, 357-362.

46. Hanemann, W.M. Welfare evaluations in contingent valuation experiments with discrete responses. Am. J. Agric. Econ. 1984, 66, 332-341. [CrossRef] 
47. Kim, Y.-H.; Jeon, E.-J.; Shin, M.-Y.; Chung, I.-B.; Lee, S.-T.; Seo, K.-W.; Pho, J.-K. A study on the baseline carbon stock for major species in korea for conducting carbon offset projects based on forest management. J. Korean Soc. For. Sci. 2014, 103, 439-445. [CrossRef]

48. Kwon, O.-B. An analysis on the economic effects of forest management extension service. Korean J. For. Econ. 2014, 21, 13-26.

49. Rafael, L.P.; Lopez-de-Silanes, F.; Shleifer, A.; Vishny, R.W. Agency problems and dividend policies. J. Financ. 2000, 55, 1-33. 